
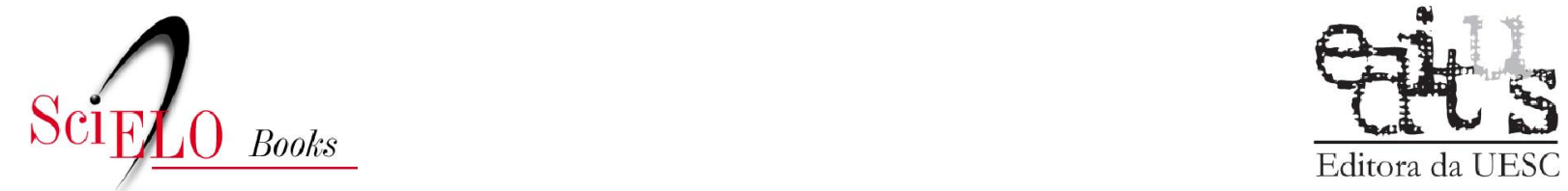

Editora da UESC

\title{
2 Histórico e tendências atuais da recuperação ambiental
}

\author{
Danilo Sette de Almeida
}

SciELO Books / SciELO Livros / SciELO Libros

ALMEIDA, DS. Histórico e tendências atuais da recuperação ambiental. In: Recuperação ambiental da Mata Atlântica [online].3rd ed. rev. and enl. Ilhéus, BA: Editus, 2016, pp. 18-21. ISBN 978-857455-440-2. Available from SciELO Books $<\underline{\text { http://books.scielo.org }>\text {. }}$

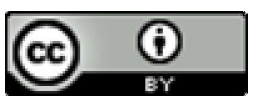

All the contents of this work, except where otherwise noted, is licensed under a Creative Commons Attribution $\underline{4.0 \text { International license. }}$

Todo o conteúdo deste trabalho, exceto quando houver ressalva, é publicado sob a licença Creative Commons Atribição 4.0.

Todo el contenido de esta obra, excepto donde se indique lo contrario, está bajo licencia de la licencia Creative Commons Reconocimento 4.0. 


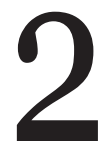

\section{HISTÓRICO E TENDÊNCIAS ATUAIS DA RECUPERAÇÃO AMBIENTAL}


$\mathrm{E}$ m todo mundo, temos a presença de áreas degradadas por diversas causas, desde o mau uso do solo na agricultura, extração de minérios, até o uso de fogo descontrolado, entre outros. Em vários países, a recuperação de áreas degradadas já era uma técnica praticada há bastante tempo, estas experiências, muitas datadas de antes de Cristo, são importantes referências, para países "jovens" como o Brasil.

Em nosso país, a primeira tentativa de recuperação de áreas ocorreu no século passado quando o Major Manuel Gomes Archer, por ordem do Imperador, iniciou, em 1886, o reflorestamento da floresta da Tijuca, neste plantio, foi utilizada uma mescla de plantas nativas e exóticas (incluindo eucaliptus). Além do plantio histórico da floresta da Tijuca, poucas iniciativas foram realizadas, destacamos o trabalho, também desenvolvido na área de floresta atlântica, de recomposição de um trecho de mata ciliar, no município de Cosmópolis, estado de São Paulo, onde o plantio foi iniciado em 1955 (NOGUEIRA, 1977). Nesta fase inicial de recuperação ambiental, no Brasil, além do pouco conhecimento da dinâmica dos ecossistemas naturais, existia uma carência muito grande de áreas de produção de mudas nativas. Estas dificuldades levaram à implantação de muitos projetos com pequena variedade de espécies, eram utilizadas as mudas que se tinha disponível, em plantios aleatórios e, muitas vezes, espécies exóticas àqueles ambientes que estavam sendo recuperados.

Com o aumento destes trabalhos, a partir da década de 1980, surgiram também novas propostas e modelos de recuperação, destacando-se os que propõem o uso da combinação das espécies de diferentes grupos ecológicos, segundo sucessão secundária, discutida por autores como Kageyama et al. (1989) e Rodrigues et al. (1990). Eles propõem o uso de modelos baseados em levantamentos florísticos e fitossociológicos de florestas remanescentes na região.

A Constituição da República Federativa do Brasil, de 1988, possui um capítulo sobre meio ambiente (art. 225), contendo inclusive a obrigatoriedade da recuperação de áreas degradadas por mineração (parágrafo $2^{\circ}$ ). Infelizmente, na Constituição, não foram consideradas áreas de estradas, áreas de preservação permanente e outras. Com as exigências legais e condicionantes de licenciamentos ambientais, diversas empresas já começam a se preocupar e a investir mais na reabilitação de áreas degradadas. 
A tendência atual, proposta neste trabalho, é que a recuperação não seja uma mera aplicação de técnicas silvicultoras, mas que se tenha um desenvolvimento de modelos de recuperação ambiental utilizando plantas nativas autóctones específicas para cada ambiente a ser recuperado, e se trabalhe com diversidade de espécies, enfocando a recuperação ambiental em um sentido mais holístico. Conforme SER (2004), a um ecossistema restaurado corresponde à recuperação da integridade, da resiliência e da sustentabilidade, proporcionando a integração com a paisagem na qual está inserido. Os novos rumos da recuperação ambiental englobam a sustentabilidade do ecossistema em processo de restauração, ou seja, esta área consegue se manter e evoluir do ponto de vista sucessional e de diversidade de espécies. Assim, não é exigido que a área retornasse a todas as características iniciais de referência (ecossistema em seu estado original naquele local, floresta primária, estágio clímax), mas consiga ser sustentável, no sentido de prosseguir o aumento contínuo da diversidade de espécies e não regrida do ponto de vista biológico. A interação maior entre restauração ecológica, envolvendo conceitos de manejo e planejamento de paisagem, é uma tendência mundial, envolvendo, então, nas etapas iniciais de planejamento da restauração, o estudo detalhado da paisagem, principalmente o entorno da área objeto da recuperação. Estes conhecimentos bióticos, juntamente com informações sobre o meio físico (solo, clima, relevo) e conceitos como o de planejamento e de ecologia de paisagem, permitem definir melhores e mais eficazes estratégias de restauração ecológica da paisagem promovendo maior integração entre a paisagem e a restauração. A Ecologia de Paisagem fornece a base para os conceitos dos corredores ecológicos e da ampliação ecológica de fragmentos florestais, estas estratégias são aplicadas eficazmente após um trabalho elaborado de planejamento de paisagem.

As novas tendências dos modelos de restauração ecológica incluem novas estratégias e modelos de recuperação, onde destacamos a recuperação ambiental com uso múltiplo, estratégia onde são considerados, no processo de recuperação, os aspectos ambientais, os aspectos sociais, econômicos, legais e culturais. Dentro desta linha, destacamos também que, no Brasil, o surgimento de iniciativas de plantios de espécies nativas para fins econômicos, existe um grande esforço no desenvolvimento de estratégias de plantios de espécies nativas, voltados para a produção econômica (produção 
madeireira e não madeireiros). A prestação de serviços ambientais (PSA) pelas florestas está cada vez mais reconhecida e estão multiplicando ações, estratégias e desenvolvimento de modelos, no sentido de promover restauração ecológica para produção de serviços ambientais (produção de água, biodiversidade, carbono etc.).

Conforme citado por Martins (2012), nas linhas metodológicas atuais, existe um enfoque comum na restauração da diversidade vegetal, das funções e processos ecológicos dos ecossistemas sem a preocupação de alcançar o clímax final. Destacamos, porém, que, mantendo a visão holística da restauração ecológica, é importante tentar se aproximar ao máximo da sequência sucessional original, trazendo para o processo de restauração o máximo de espécies nativas autóctones representantes do ecossistema e do ambiente, que está sendo restaurado, a aproximação máxima da vegetação/ecossistema original vai depender destas ações e estratégias. 